\title{
The Influence of Blended Learning And Learning Independence On Student Learning Outcomes In Economics Subjects
}

\author{
Khoirul Pahmi, Indra Maipita, M. Yusuf \\ Universitas Negeri Medan, Indonesia \\ khoirulpahmi99@gmail.com
}

\begin{tabular}{ll}
\hline Article History & Received : Feb $9^{\text {th }} 2021$ \\
& Revision : April $13^{\text {th }} 2021$ \\
& Publication : June $30^{\text {th }} 2021$ \\
\hline
\end{tabular}

\begin{abstract}
Educational work is always in a world that is constantly changing along with the advancement of information technology and demographic changes. If the world of education is not biased to adjust to the development of the times and demographic graying is also soasial, education will become obsolete and not aligned with the educational objectives that have been formulated, especially with changes that occur due to the pandemic that requires schools to implement mixed learning or blended learning. The purpose of this study is to find out the difference in learning outcomes of students who use blended learning models using conventional models and to know how far students learn outcomes in economics subjects after the implementation of blanded learning models. This research is an experimental study with Factorial Design $2 \times 2$ (ANAVA Two Way) involving 3 variables, namely the free variable is a blended learning model, the bound variable is the result of studying the economics of students of Sma Negeri 1 Gunung Tuleh and the moderating variable is the independence of students' learning. The population in this research is as many as 4 classes and the sample is as many as 2 classes. The results of this study showed that the experimental class score for the category of high learning independence has a higher average student learning outcome of 83.6 compared to the control class with a score of 78.9, while for low learning independence the average results of experimental class learning is higher at 57.5 compared to the control class with a score of 54.1. Based on the results of statistical analysis with a two-track ANAVA showed that the results of the first hypothesis test obtained Fhitung > Ftabel, namely $18.63>2.74$ and spss-22 results for the learning model obtained $0.00<0.05$, then Ho was rejected and Ha accepted. The conclusion obtained that there is a difference between student learning outcomes in the expository learning model class and student learning outcomes in blanded learning model classes.
\end{abstract}

Keywords: blended learning, self-reliance of learning and student learning outcomes. 


\section{Introduction}

The increasing human power and the birth of new technologies, became the background of the birth of the learning model blended learning as a new innovation to answer the challenges of change or progress zsafe. Blended learning is a term of mixing between two learning models, namely conventional learning models that are commonly done face to face or face-to-face lansgung with internetbased learning models commonly known as e-learning (Uno, 2011). This learning model can be applied to students at all levels, especially for those with high mobility. Another reason is as a means of learning together for students who feel they need additional materials.

One of the efforts that can be doneto achieve the competence of the twentieth century one of them is to use problem-based learning. As Bruner stated that problem based learning methods have advantages such as students will more easily understand basic concepts and ideas better, help use memory and transfer in new situations of the teaching and learning process, and encourage students to think initiative (Anam 2016:16).

However, discovery-based learning is rather difficult to implement in schools because it requires a relatively longer learning time. Based on interviews with teachers of economics subjects that states that teachers very rarely use even avoid problem based learning models because this learning model is less effective applied considering the limited learning time in schools.

In an effort to overcome the problem of learning time in school, teachers usually apply teaching methods such as lectures and giving practice questions. This method was chosen with the intention to enrich students' ability to solve problems on economic materials as well as an effort to speed up the process ofstudents. Nevertheless, students claim that they still have difficulty in studying economic materials. Learning difficulties experienced by these students usually occur because students do not understand the correct concepts in the materials taught. In addition, the lack of varied learning methods applied by teachers contributes to students' learning difficulties.

In the observations made by researchers, although it has been supported by adequate ICT, teachers have never provided economic materials online. In fact, the fact that teachers can take advantage of handpond owned by every student. Integrating ICT can be done by combining face-to-face learning (conventional) with online learning or better known as blended learning. Melton et al. (2009:11) stated that student achievement results using blended learning are higher than traditional learning. 


\section{LITERATURE REVIEW \\ Blended Learning Model}

Blended Learning comes from the word Blended and Learning which if interpreted in Indonesian Blended is combining with good or the right measure and Learning is learning. Of the two words, it can be interpreted that Blended Learning is combining two or more learning models that can be combined into a well-applied learning model (Deklara, et al: 2018). The term Blended Learning is mun cul because the development of information and communication technology (ICT) is currently very rapid, thus encouraging the world of education to use this ICT media in the learning process. Blended learning can combine the positive aspects of two learning environments, namely learning conducted in the classroom with e-learning (Sutopo, 2012:168).

\section{Characteristics of Blended Learning Model}

Characteristics of blended learning models: (a) Learning that combines different ways of delivering teaching models, learning styles, and various technology-based media, (b) As a combination of face-to-face, self-learning, and online learning, (c) Learning supported by an effective combination of delivery, teaching, and learning styles, (d) Teachers and parents of learners have i equally important role, teacher as facilitator, and parent as supporter (Husamah 2013: 16)

The Purpose of using Blended Learning learning model: (a) Helping learners to develop better in the learning process according to learning style and preferences in learning, (b) Providing practical-relistis opportunities for teachers and learners to learn independently, usefully and continuously, (c) Improved scheduling flexibility for learners, by combining the best areas of face-to-face and online learning. Face-to-face classes can be used to engage students in interactive experiences, while the online portion provides students with knowledge-rich multimedia content anytime and anywhere, as long as students have internet access,( Husamah 2013: 22)

\section{Problem Based Learning Model}

The use of learning strategies is very important to support the achievement of learning objectives. Problem Based Learning is based on the theory of cognitive psychology. According to Barrows PBL is a learning model based on the principle of case use (problem) as the point of origin to gain and integrate new knowledge. The focus is not much on what the student is doing, but on what the student thinks during the work,(Jusuf, 2009:1). Problem Based Learning (PBL) is a learning model that involves students to solve problems through the stages of scientific methods 
so that students can learn knowledge related to the problem and at the same time have the skills to solve problems (Kamdi 2007: 77)

Problem Based Learning (PBL) is a series of learning activities that emphasize the process of solving problems faced scientifically. The nature of the problems raised in Problem Based Learning is the gap between the real situation and the expected situation, or between what happens with expectations. (Sanjaya 2006: 214). The purpose of learning using problem based learning (PBL) learning model: (a) Developing thinking skills and problem solving skills, (b) Learning the role of adults, intended to help students work in real-life situations, (c) Skills for selflearning, it is expected that students can learn to handle the tasks of finding solutions independently in their later life. (Sanjaya, 2006)

\section{Google Classroom as a Learning Medium}

Google Classroom as an alternative to learning In the early stages of 20142016 initially google classroom was not intended for everyone but only schools that cooperate with google, but the following year google classroom can be accessed by everyone using google personal. This can be utilized by teachers, students and parents in learning, so there is no need for cooperation with google. Open use can benefit google classroom users. Research conducted by Shampa Iftakhar (2016) under the title Google Classroom: What Works and How? contains about that google classroom helps to monitor students for learning. Teachers can see all students' activities during learning in google classroom. Interaction between teachers and students is well recorded

\section{Self-Reliance of Learning}

Self-reliance is very closely related in daily life. With self-reliance one will determine the actions taken by the person will act good or bad. This is also the case in the world of education, in the context of the teaching and learning process a student is required to learn independently and not depend on others. (Rusman 2010)

Rusman (2010: 355) suggests that the most important thing in the selflearning process is to see the improvement of students' skills and skills in the teaching and learning process without the help of others. In self-learning students will try to understand the content of the lesson themselves, if they get difficult then students discuss it with the teacher or with fellow students.

The role of a teacher in self-learning is only as a facilitator and is not the only source of knowledge. In self-study, students are free to determine directions, plans, resources, and decisions to achieve academic goals. Naturally the child will have the urge to be independent and responsible for themselves. Self-reliance always helps 
the learning process by activating knowledge, strengthening and securing that has been learned, as well as providing motivation in relation to the willingness to learn.

Some indicators that can be used to measure learning independence are: 1) learning initiatives, 2) diagnosing learning needs, 3) setting learning goals and objectives, 4) monitoring, organizing and controlling learning progress,5) viewing difficulties as challenges, 6) utilizing and finding relevant sources, 7) choosing and implementing learning strategies, 8) evaluating learning processes and outcomes and 9) having self-concept or self-concept. (Sumarmo, 2004)

\section{Results of Learning}

The changes experienced as a result of learning are the result of learning. Thus, the learning outcomes are indicators to measure students' ability in the learning process. The learning outcomes describe the abilities students have in both cognitive, affective, and psychomotor aspects. (Sanjaya, 2012). Learning outcomes are also changes that result in people changing their attitudes and behaviors, (Purwanto 2011). The realm of change refers to the taxonomy of teaching purposes developed by Bloom that include the cognitive, affective and psychomotor spheres. It can be concluded that learning outcomes are an ability in the mastery of knowledge gained from learning experience and can change the attitudes or behaviors of learners that can be assessed by means of tests or nontests to know the progress during a certain period of the year that covers three areas, namely the cognitive realm, affective realm, and psychomotor realm.

Therefore, researchers are interested in conducting experimental research that will compare student learning outcomes by applying a mixed learning model that is applying a problem based learning model that is combined with the use of Google Classroom that will be compared to the application of expository learning models or conventional models seen from student learning independence.

This study aims to: (a) Know how far students learn outcomes in economics subjects after the implementation of blanded learning models, (b) Knowing the difference in student learning outcomes using blended learning models using conventional models, (c) Knowing if there is an interaction between low learning independence and high learning independence to student learning outcomes with the use of blended lea learning models rning

\section{METHODS}

The school that was used as a research site was SMA N 1 Gunung Tuleh in west pasaman district of west Sumatra in kelas XI IPS. The population in this study is all students of grade XI IPS numbering 146, Sampling Techniques pada this study is a random retrieval (cluster random sampling) consisting of 4 classes that will be selected later into two classes, namely one control class and one experimental 
class and the sample in this study is class XI IPS 1 and class XI IPS 2 with the number of students as many as 74 students.

This research is a factorial design experiment research $2 \times 2$ as below:

Factorial Research Design 2 x 2 (ANAVA Two Way)

\begin{tabular}{|l|l|l|}
\hline Learning Model (A) & $\begin{array}{l}\text { Blended } \\
\text { learningmodel(A1) }\end{array}$ & $\begin{array}{l}\text { Expository learning } \\
\text { model (A2) }\end{array}$ \\
\hline $\begin{array}{l}\text { Self-reliance of learning } \\
\text { (B) }\end{array}$ & A1B1 & A2B1 \\
\hline Height (B1) & A1B2 & A2B2 \\
\hline Low (B2) & & \\
\hline
\end{tabular}

Treatment Procedure, The same treatment of research subjects to experimental subjects include: (a) Treatment refers to the same specific learning objectives that are the results of integrated IPS economic learning in class XI, (b) Treatment in learning activities is given in the same school that is in the classroom with facilities and time according to the lesson schedule, (c) Treatment is given by the same teacher, namely teachers in the field of economic studies, has been certified and experienced teaching more than fifteen years, (d) The duration of treatment in each class requires 7 meetings in the classroom.

Implementation of Treatment, Treatment given is: (a) In the experimental class in the implementation of blended learning learning model that is to communicate between problem based learning learning model with google classroom, (b) In the control class applied expository learning model.

Data collection techniques are a strategic step in research, because the main purpose of research is to obtain data. This study uses several data collection techniques, namely: Documentation,Observation, Tests, Questionnaires.

The instruments used in this study are subjective tests or multiple choice tests. To measure the validity of the question that will be used as a research instrument, researchers first test the instrument on students outside the research sample. This validity is sought by correlate the score of each item with the total score. This validity calculation uses the product moment formula:

$$
r_{\text {hitung }}=\frac{N \sum X Y-\left(\sum X\right)\left(\sum Y\right)}{\sqrt{\left\{\sum X^{2}-\left(\sum X\right)^{2}\right\}\left\{N \sum Y^{2}-\left(\sum Y\right)^{2}\right\}}}
$$

To find out the reliability level used the formula alpha cronbach (Arikunto, 2012) :

$$
\mathrm{r}_{11}=\left(\frac{n}{n-1}\right)\left[1-\frac{\sum \sigma_{i}^{2}}{\sigma^{2} i}\right]
$$

The question is stated well when the question is not very easy and not too difficult in other words the degree of difficulty of the question is moderate or sufficient. The magnitude of the problem difficulty index figure ranges from 0.00 to 1.00. The difficulty index of the question is calculated by using the following formula: 


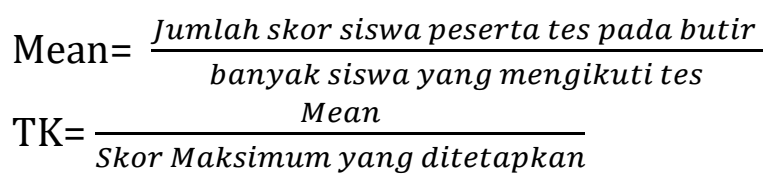

Hypothesis testing is conducted to prove the correctness of the hypothesis that has been established so that it is obtained whether the hypothesis designed in the study is accepted or rejected. Testing criteria, if $\mathrm{F}_{\text {calculates }}>\mathrm{F}_{\text {table }}$ at a significant level selected with $\mathrm{db}$ numerator is the appropriate $\mathrm{db}$ numerator then Ho is rejected or there is an average difference between the groups that areuiji and vice versa

\section{RESULTS AND DISCUSSION}

Based on the data the learning results obtained the lowest $\left(x_{\min }\right)$ score, and the highest score and average score for the experimental class and control class the following $\left(x_{\max }\right)(\bar{x})$ table.

Table 4.1 Student Economic Postest Results Data

\begin{tabular}{|l|c|c|c|c|}
\hline \multirow{2}{*}{ class } & \multicolumn{4}{|c|}{ Value of Students' Economic Learning Outcomes } \\
\cline { 2 - 5 } & $\boldsymbol{X i}_{\min }$ & $\boldsymbol{X i}_{\max }$ & $\overline{\boldsymbol{X}}$ & SD \\
\hline experiment & 45 & 95 & 71,5 & 14,9 \\
\hline control & 42,5 & 82,5 & 64,4 & 13,4 \\
\hline
\end{tabular}

The data in the table showed that the minimum score of student learning outcomes in the experimental class was higher than the control class and also the maximum score of the experimental group students' learning outcomes was higher than that of the control class. The average learning outcome of experimental class students is higher compared to the control class.

Table 4.2 Student Economic Learning Outcomes Data By Category of Learning Independence

\begin{tabular}{|c|c|c|c|c|}
\hline $\begin{array}{c}\text { Category of } \\
\text { Learning } \\
\text { Independence }\end{array}$ & $\begin{array}{c}\text { Average } \\
\text { Experimental } \\
\text { Class } \\
\text { Learning } \\
\text { Outcomes }\end{array}$ & $\begin{array}{c}\text { Number of } \\
\text { Students }\end{array}$ & $\begin{array}{c}\text { Average } \\
\text { Control Class } \\
\text { Learning } \\
\text { Outcomes }\end{array}$ & $\begin{array}{c}\text { Number of } \\
\text { Students }\end{array}$ \\
\hline tall & 83,6 & 20 & 78,9 & 19 \\
\hline low & 57,5 & 18 & 54,1 & 17 \\
\hline
\end{tabular}

The table above shows the average economic learning outcomes of U.S. students in the high learning independence category having higher average student learning outcomes than the control class. As for the independence of low learning the average results of experimental class learning are higher than the control class. 


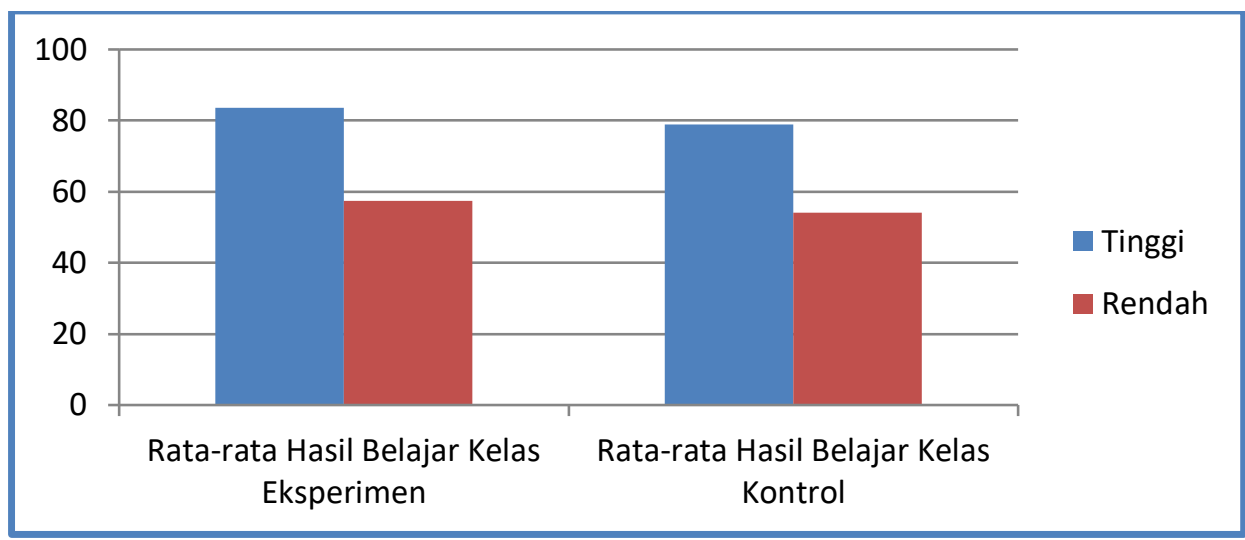

Figure 4.1 Student Economic Learning Outcomes Chart by Category of Learning Independence

Hypothesis testing was conducted using a $2 \times 2$ factorial variance analysis (ANAVA) technique. Based on the calculation of ANAVA $2 \times 2$ obtained $\mathrm{F}_{\text {count }}=16.63$ while the value of $\mathrm{F}_{\text {table }}=3.97$ for $\mathrm{dk}(1.70)$ and significant level 5\%. It turns out that the value of $F_{\text {count }}>F_{\text {table, So that }} \mathrm{H}_{\mathrm{o}}$ is rejected and $\mathrm{H}_{\mathrm{a}}$ is accepted. So the results of economic learning of students who are taught with blanded learning model is better than that taught by expository learning model. Based on the calculation of ANAVA 2 $\mathrm{x} 2$ obtained $\mathrm{F}_{\text {count }}=208.17$ while the value $\mathrm{F}_{\text {table }}=3.97$ for $\mathrm{dk}(1.70)$ and a significant level of 5\%. It turns out that the value of $\mathrm{F}_{\text {count }}>\mathrm{F}_{\text {table, so that }} \mathrm{H}_{\mathrm{o}}$ is rejected and $\mathrm{H}_{\mathrm{a}}$ is accepted. Therefore, the results of economic learning of students with high learning independence are better than the results of learning economics students with low independence. Based on factorial anava calculation of $2 \times 2$ obtained $F_{\text {count }}$ $=4.43$ while the value of table $\mathrm{F}=3.97$ for $\mathrm{dk}(1.70)$ and significant level of $5 \%$. It turns out that the value of $\mathrm{F}_{\text {count }}>\mathrm{F}_{\text {table, }}$, so that $\mathrm{H}_{\mathrm{o}}$ is rejected and $\mathrm{H}_{\mathrm{a}}$ is accepted. So there is an interaction between the learning model and the independence of learning in giving influence terhada economic learning results students tested the truth.

The results of Scheffe's test calculation can be seen in the table below 4.9:

table. 4.8 Scheffe Test Calculation Results

\begin{tabular}{|c|c|c|c|}
\hline No & Treatment Group & F count & Ftable \\
\hline $\mathbf{1}$ & $\mathrm{A}_{1}$ dan $\mathrm{A}_{2}$ & 16,63 & 2,74 \\
\hline $\mathbf{2}$ & $\mathrm{B}_{1}$ and $\mathrm{B}_{2}$ & 209,57 & 2,74 \\
\hline $\mathbf{3}$ & $\mathrm{A}_{1} \mathrm{~B}_{1}$ dan $\mathrm{A}_{2} \mathrm{~B}_{1}$ & 20,67 & 2,74 \\
\hline $\mathbf{4}$ & $\mathrm{A}_{1} \mathrm{~B}_{2}$ dan $\mathrm{A}_{2} \mathrm{~B}_{2}$ & 2,85 & 2,74 \\
\hline $\mathbf{5}$ & $\mathrm{A}_{1} \mathrm{~B}_{1}$ dan $\mathrm{A}_{1} \mathrm{~B}_{2}$ & 73,8 & 2,74 \\
\hline $\mathbf{6}$ & $\mathrm{A}_{2} \mathrm{~B}_{1}$ dan $\mathrm{A}_{2} \mathrm{~B}_{2}$ & 133,5 & 2,74 \\
\hline
\end{tabular}

The first result showed that the first hypothesis test result obtained $\mathrm{F}_{\text {calculates }}$ $>F_{\text {table, }}$ which is $16.63>2.74$ and spss-22 results for the learning model obtained 
$0.00<0.05$, then $\mathrm{H}_{\mathrm{o}}$ rejected and $\mathrm{H}_{\mathrm{a}}$ accepted. The conclusion obtained that there is a difference between student learning outcomes in the expository learning model class and student learning outcomes in blanded learning model classes. The results of this study are in line with research conducted by Gede Sandi (2012) entitled The Influence of Blended Learning on Chemical Learning Results Reviewed From Student Independence. This study aims to determine the influence of blended learning on the results of chemistry learning reviewed from the independence of students. This study uses quasi experiment method with posttest only control group design.

The second result shows that the second hypothesis test result obtained $\mathrm{F}_{\text {calculates }}>\mathrm{F}_{\text {table, }}$ namely $209.57>2.74$ and SPSS-22 results for the learning model obtained $0.00<0.05$, then $\mathrm{H}_{\mathrm{o}}$ rejected and $\mathrm{H}_{\mathrm{a}}$ accepted. The conclusion obtained that there is a difference between the results of economic learning with the independence of high learning and the results of economic learning with low learning independence. The results of the study are in line with the results of research Pratistya Nor Aini1 Dan Abdullah (2012) Entitled The Influence of SelfReliance of Learning And Student Learning Environment On The Achievement of Learning Accounting Students Class Xi Ips Sma Negeri 1 Sewon Bantul School Year $2010 / 2011$.

The third result shows that the results of the third hypothesis test obtained $\chi^{2}$ by calculating the $<\chi^{2}$ table of $5.44<7.81$ and spss- 22 results for the learning model obtained $0.043<0.05$ then $\mathrm{H}_{0}$ rejected and $\mathrm{H}_{a}$ accepted. So there is an interaction between the results of economic learning with the learning model and the independence of learning. This shows that the learning model and the humanity of learning simultaneously influence students' economic learning outcomes. The results of this study are also in line with research by putri fitriasari and novita sari (2017) with the title of implementation of blended learning to increase student learning independence in numerical method courses. The study stated that there is an influence of interaction between learning and KAM on improving student learning independence.

The fourth result based on the results of scheffe test calculation obtained $\mathrm{F}_{\text {count }}=20.67$ higher than $\mathrm{F}_{\text {table }}=2.74$ at a significant level of $5 \%$. Thus $\mathrm{H}_{\mathrm{o}}$ is rejected and $\mathrm{H}_{a}$ is accepted. This means that the economic learning outcomes of students who are taught with blanded learning models and have higher learning independence compared to the economic learning outcomes of students who are taught with expository learning models and have high learning independence.

The fifth result based on scheffe test calculation result obtained $\mathrm{F}_{\text {count }}=2.85$ higher than $\mathrm{F}_{\text {table }}=2.74$ at a significant level of $5 \% . \mathrm{H}_{\mathrm{o}}$ rejected and $\mathrm{H}_{\mathrm{a}}$ accepted. Means the results of economic learning students who are taught with blanded learning model and have low learning independence is higher than the economic 
learning outcomes of students who are taught with expository learning models and have low learning independence.

The sixth result based on the results of scheffe test calculation obtained $\mathrm{F}_{\text {count }}=133.5$ higher than $\mathrm{F}_{\text {table }}=2.74$ at a significant level of $5 \% . \mathrm{H}_{\mathrm{o}}$ rejected and $\mathrm{H}_{\mathrm{a}}$ accepted. Means the results of economic learning students who are taught with blanded learning model and have higher learning independence compared to the economic learning outcomes of students who are taught with blanded learning model and have low learning independence.

The various limitations in this study include: (a) The time used in this study is limited. So that the results obtained are less than maximum,(b) This research was conducted during the covid-19 pandemic, as a result of which the teaching and learning process does not fully run normally. (c) This study was conducted in areas with uneven internet network conditions, (d) This study is limited to the variables of learning independence as variables that describe the characteristics of students, so have not seen the overall variables that affect the acquisition of student economic learning outcomes.

\section{CONCLUSION}

Based on the results of the analysis and discussion can be taken Conclusion:

a. The results of student economic learning that are taught by blanded learning model are higher than the economic learning outcomes of students who are taught with expository learning models.

b. The economic learning outcomes of students who have high learning independence are higher than the economic learning outcomes of students who have low learning independence.

c. There is an interaction between the learning model and the independence of learning to the results of students' economic learning. The learning model and the humanity of learning simultaneously influence students' economic learning outcomes. 


\section{REFERENCE}

Anam, Khoirul. (2016). Pembelajaran Berbasis Inkuiri. Yogyakarta: Pustaka Pelajar

Arikunto, Suharsimi. (2012). Prosedur Penelitian.Jakarta:n Rineka Cipta

Deklara Nanindya,dkk.(2018). "Daya Tarik Pembelajaran di Era 21 Dengan Blended Learning". Jurnal teknologi Pendidikan,Vol 1 Nomor 1

Husamah. (2013). Pembelajaran Bauran (Blended Learning) Terampil Memadukan Keunggulan Pembelajaran Face-To-Face, E- learning fine

Online, dan Mobile Learning. Jakarta: Prestasi Pustaka

Kamdi. 2007. Strategi Pembelajaran. Bandung:PT Remaja Rosdakarya

Melton, B., Helen, G., \& Joanne, C.F. 2009. Achievement and Satisfication in Blended Learning Traditional General Health Course Designs

Purwanto. (2011). Evaluasi Hasil Belajar. Yogyakarta: Pustaka Pelajar

Rusman. (2010). Model-model Pembelajaran (Mengembangkan Profesionalisme Guru Edisi Kedua). Jakarta: Raja Grafindo Persada

Sanjaya, Wina. (2006). Strategi Pembelajaran Berorientasi Standar Proses Pendidikan. Jakarta: Prenada Media Group

Sanjaya, Wina. (2012). Strategi Pembelajaran Berorientasi Standar Proses Pendidikan.Jakarta: Kencana.

Shampa Iftakhar. (2016). GOOGLE CLASSROOM: WHAT WORKS AND HOW?. Journal of Education and Social Sciences, Vol. 3, (Feb.) ISSN 2289-9855

Sumarmo, U. (2004). Kemandirian Belajar : Apa, Mengapa, dan Bagaimana Dikembangkan pada Peserta Didik. Laporan Penelitian Hibah Pascasarjana

UPI. Bandung

Sutopo, H. Ariesto. (2012). Teknologi Informasi dan Komunikasi dalam Pendidikan. Yogyakarta: Graha Ilmu

Uno, Hamzah B. (2011). Model Pembelajaran: Menciptakanproses Belajar Mengajar Yang Kreatif Dan Efektif. Jakarta: Bumi Aksara

Yamin, Martinis. (2013). Strategi dan Metode dalam Model Inovasi Pembelajaran. Jakarta: Gaung Persada Press Group

Yusuf, Syamsu. (2009). Program Bimbingan dan Konseling di sekolah. Bandung : Rizqi PressMelton, B., Helen, G., \& Joanne, C.F. 2009. Achievement and Satisfication in Blended Learning Traditional General Health Course Designs

Purwanto. 2011. Evaluation of Learning Outcomes. Yogyakarta: Student Library Rusman. (2010). Learning Models (Developing Professionalism

Teacher Second Edition). Jakarta: Raja Grafindo Persada

Sanjaya, Vienna. (2006). Education Process Standard Oriented Learning Strategy. Jakarta: Prenada Media Group 
Sanjaya, Vienna. (2012). Standard-Oriented Learning Strategy of The Educational Process.Jakarta: Kencana.

Shampa Iftakhar. (2016). GOOGLE CLASSROOM: WHAT WORKS AND HOW? Journal of Education and Social Sciences, Vol. 3, (Feb.) ISSN 2289-9855

Sumarmo, U. (2004). Self-Reliance learning: What, Why, and How It Is Developed in Learners. UPI Graduate Grant Research Report. Bandung

Sutopo, H. Ariesto. (2012). Information and Communication Technology in Education. Yogyakarta: Graha Ilmu

Uno, Hamzah B. (2011). Learning Model: Creating a Creative and Effective Teaching And Learning Process. Jakarta: Bumi Aksara

Yamin, Martinis. (2013). Strategies and Methods in the Learning Innovation Model. Jakarta: Gaung Persada Press Group

Yusuf, Shamsu. (2009). Guidance and Counseling Program in schools. Bandung : Rizqi Press 